\title{
Effect of different planting times on the quantitative variation of total seed isoflavone content and composition in Korean soybean cultivars (Glycine max (L.) Merr.)
}

\author{
Hong-Sik Kim ${ }^{1} \cdot$ Beom-Kyu Kang ${ }^{1}$. Jeong-Hyun Seo ${ }^{1}$ Hyun-Tae Kim ${ }^{1} \cdot$ Tae-Joung Ha ${ }^{1}$ Jae-Hyeon $\mathrm{Oh}^{2}$. \\ Sang-Ouk Shin ${ }^{1} \cdot \operatorname{In}-$ Yeol Baek ${ }^{1}$
}

Accepted: 4 September 2020 / Published online: 17 September 2020

(c) The Author(s) 2020

\begin{abstract}
There is great interest in the enhancement of isoflavones as one of the functional ingredients in soybean. This study aimed to investigate the effects of changes in the ecological environment over different planting times on isoflavone content. A total of 28 Korean soybean cultivars were grown at different planting times in late May, mid-June, and early July and their isoflavone content was measured over 2 years (2017 and 2018). Analyses of variance revealed significant effects of genotypes, planting times, years, and their interactions on isoflavone content. The average content of total isoflavone, as well as its component groups of malonylglucoside and aglycon, increased significantly as the seed planting time was delayed from late May to early July. The accumulation of each isoflavone component varied with changes in the planting time. The isoflavone content of the soybean cultivars for soy-sprout and soy-paste and tofu were higher for plantings in early July than for those in late May and/or mid-June, except for the black soybean cultivars. Despite significant correlations of the isoflavone content of the 28 cultivars among the three planting times, the responses of individual cultivars varied in isoflavone content by planting time. When planting was delayed, the time to flowering and maturity was also delayed and the number of days of growth from planting or flowering to maturity decreased; however, this was not related to isoflavone content. When planting was delayed, the temperature during the ripening period from flowering to maturity was lower, which was inversely related to the isoflavone content.
\end{abstract}

Keywords Soybean $\cdot$ Isoflavone $\cdot$ Aglycone $\cdot$ Glucoside $\cdot$ Malonylglucoside $\cdot$ Acetylglucoside $\cdot$ Planting time $\cdot$ Environment

\section{Introduction}

Isoflavone, together with coumestan and lignan, has a similar structure and efficacy to the female hormone estrogen; therefore, it is called phytoestrogen and is especially abundant in soybean. Isoflavone in soybeans is a polyphenolic component that acts as an antioxidant in the defense system of the plant against abiotic and biotic external stresses

Hong-Sik Kim

kimhongs@korea.kr

1 Department of Southern Area Crop Science, National Institute of Crop Science, Rural Development Administration, Miryang 50424, Republic of Korea

2 Gene Engineering Division, Department of Agricultural Biotechnology, National Institute of Agricultural Sciences, Rural Development Administration, Jeonju 54874, Republic of Korea
(Aliferis et al. 2014; Gutierrez-Gonzalez et al. 2010; Phillips and Kapulnik 1995). The efficacy of bone health that helps in the bioactive functioning of the human body has been proven previously (Lee et al. 2019; Messina 2000); thus, soybean isoflavone has been used as a functional raw material for healthy functional foods. Soybean is not only a major source of plant protein, but also attracts attention as a raw material for healthy food. The soybean is the second most important food crop after rice and is the main ingredient of the traditional Korean diet, including soy-paste, tofu, and soy-sprout. Therefore, the possibility of ingesting and utilizing soybean functional ingredients such as isoflavone is very high (Kim et al. 2001).

It is known that soybean (Glycine max (L.) Merr.) contains approximately $0.1-0.4 \%$ isoflavone, with the content and composition differing significantly based on the cultivars and cultivation environment, such as the location and cultivation year (Britz et al. 2011; Carrera et al. 2011; Hoeck 
et al. 2000; Murphy et al. 2009). Previous studies have verified highly significant variations in isoflavone content among soybean cultivars with different genetic backgrounds. Kim et al. (2019) reported that the variation effect in isoflavone content due to genetic factors was large, with the broadsense heritability values for each component group of isoflavones found to be as high as $0.8-0.92$, except for the acetylglucoside group (0.12). The same cultivar can have different isoflavone contents, which is influenced by environmental factors. In particular, different levels of isoflavone content have been reported based on the cultivation environments such as planting time and fertilization level, different weather conditions, and the altitude of the cultivation area (Hasanah et al. 2015; Lee et al. 2003; Yi and Yoon 2012; Yun et al. 2006).

Although there are various functional ingredients in soybean, limited studies have been conducted regarding their enhancement. Soybean cultivars must be developed with high isoflavone content for their industrialization enduses, which include as general food and in functional diets and cosmetics. Determining the effects of the cultivation environment and methods on the isoflavone content is also important for their practical use in soybean production sites. Soybean cultivars may not be always planted on time owing to atypical weather and/or field conditions; thus, they are often sown intentionally early or late to avoid poor environmental conditions. This change in cultivation time causes various physiological reactions of soybean cultivars to the ecological environment, such as temperature and photoperiod, for their flowering and maturation. The present study aimed to investigate the effects of changes in ecological environments with different planting times on soybean isoflavone content and compositional variation.

\section{Materials and methods}

\section{Plant materials and field experiments}

A total of 28 soybean cultivars that were grown mainly in Korea or had been recently developed were included in the present study. These cultivars were classified based on their enduses, i.e., 11 cultivars for soy-paste and tofu, 11 cultivars for soy-sprouts, and six cultivars for cooking with rice (Table 1). They were grown over 2 years, 2017 and 2018, at the Daegu experimental field site at the Department of Southern Area Crop Science of the National Institute of Crop Science, RDA in Habin-myeon, Dalseong-gun, Gyeongsangbuk-do, Republic of Korea. The planting dates occurred at three different times of 3-week intervals for each year; the first planting was in late May (May 29, 2017 and May 23, 2018), the second was in mid-June (June 14, 2017 and June 12, 2018), and the third was in early July (July 10, 2017 and July 4, 2018). The design of the field experiment, planting of seeds, and management of the experimental field were conducted according to the methodology described by Kim et al. (2019). The numbers of days to flowering and/or maturity from planting were measured for the individual cultivars in each year. The harvested seeds were dried for 3 days, threshed, and then selected for subsequent analysis. The 100-seed weight trait of individual cultivars was measured using three repetitions. To determine the effect of the climatic conditions on the isoflavone accumulation, meteorological data such as average temperature and precipitation during the ripening period from flowering to maturity were investigated for the individual cultivars. The weather data in Daegu were obtained from the Korea Meteorological Administration website (https://www.weather.go.kr/).

\section{Isoflavone analysis}

Seed samples of the 28 soybean cultivars in the three sowing time experiments were crushed using a 100-mesh size without breaking the seed coat using a vibrating sample mill (T1-100 model, CMT Co Ltd., Tokyo, Japan) and stored in a $4{ }^{\circ} \mathrm{C}$ refrigerator until subsequent isoflavone analysis. For calibration, isoflavone standards of daidzein, glycitein, genistein, daidzin, glycitin, and genistin were purchased from Sigma (St. Louis, MO, USA). Other standards of 6"-O-malonyldaidzin, 6"-O-malonylglycitin, 6"-O-malonylgenistin, 6"-O-acetyldaidzin, 6"-O-acetylglycitin, and 6"-O-acetylgenistin from Nacalai Tesque Inc. (Kyoto, Japan) were used. Seed sample preparations for soy isoflavone extraction and quantification using high-performance liquid chromatography for total isoflavone and its components were undertaken following the procedures described by Kim et al. (2019).

\section{Statistical analysis}

Analyses of variance were performed using the general linear model procedure (PROC GLM) in SAS 9.4 (SAS Institute Inc., USA). This linear model used the effect of genotypes, planting dates, replication, years, and their interactions among the components. Comparisons between the means of cultivars for each isoflavone component were made using the least significant difference at a 0.05 probability level. Pearson's correlation was calculated using PROC CORR in SAS 9.4 (SAS Institute Inc., USA) to determine the relationship among the pairs of variables of agronomic traits or meteorological data and the isoflavone content in the 28 soybean cultivars for the various planting dates. 
Table 1 List of the 28 Korean soybean cultivars classified by their end-uses

\begin{tabular}{|c|c|c|c|c|c|c|}
\hline No & Name & End-use & Year & Flower color $^{\mathrm{a}}$ & $\begin{array}{l}\text { Seed- } \\
\text { coat } \\
\text { color }^{b}\end{array}$ & 100-seed wt.(g) \\
\hline 1 & Taekwangkong & Soy-paste and Tofu & 1991 & $\mathrm{P}$ & $\mathrm{Y}$ & 25.3 \\
\hline 2 & Daewonkong & Soy-paste and Tofu & 1997 & W & $\mathrm{Y}$ & 25.6 \\
\hline 3 & Saedanbaek & Soy-paste and Tofu & 2010 & W & $\mathrm{Y}$ & 20.7 \\
\hline 4 & Uram & Soy-paste and Tofu & 2010 & $\mathrm{~W}$ & $\mathrm{Y}$ & 25.8 \\
\hline 5 & Neulchan & Soy-paste and Tofu & 2011 & W & $\mathrm{Y}$ & 21.7 \\
\hline 6 & Jinpung & Soy-paste and Tofu & 2012 & $\mathrm{P}$ & $\mathrm{Y}$ & 23.0 \\
\hline 7 & Taeseon & Soy-paste and Tofu & 2013 & $\mathrm{P}$ & $\mathrm{Y}$ & 22.2 \\
\hline 8 & Seonpung & Soy-paste and Tofu & 2013 & W & $\mathrm{Y}$ & 25.9 \\
\hline 9 & Daepung2ho & Soy-paste and Tofu & 2014 & W & $\mathrm{Y}$ & 20.9 \\
\hline 10 & Daechan & Soy-paste and Tofu & 2014 & W & $\mathrm{Y}$ & 24.5 \\
\hline 11 & Miso & Soy-paste and Tofu & 2014 & W & $\mathrm{Y}$ & 28.2 \\
\hline 12 & Pungsannamulkong & Soy-sprout & 1996 & $\mathrm{P}$ & $\mathrm{Y}$ & 10.1 \\
\hline 13 & Sorog & Soy-sprout & 2001 & $\mathrm{P}$ & PG & 11.9 \\
\hline 14 & Bosug & Soy-sprout & 2003 & $\mathrm{P}$ & $\mathrm{Y}$ & 8.6 \\
\hline 15 & Pungwon & Soy-sprout & 2006 & W & $\mathrm{Y}$ & 10.9 \\
\hline 16 & Sinhwa & Soy-sprout & 2007 & $\mathrm{P}$ & $\mathrm{Y}$ & 12.1 \\
\hline 17 & Wongwang & Soy-sprout & 2007 & $\mathrm{P}$ & $\mathrm{Y}$ & 10.9 \\
\hline 18 & Sohwang & Soy-sprout & 2008 & $\mathrm{P}$ & $\mathrm{Y}$ & 8.5 \\
\hline 19 & Haepum & Soy-sprout & 2012 & W & $\mathrm{Y}$ & 10.4 \\
\hline 20 & Haewon & Soy-sprout & 2014 & $\mathrm{P}$ & $\mathrm{Y}$ & 8.1 \\
\hline 21 & Soyeon & Soy-sprout & 2015 & $\mathrm{~W}$ & $\mathrm{Y}$ & 10.1 \\
\hline 22 & Aram & Soy-sprout & 2016 & $\mathrm{P}$ & $\mathrm{Y}$ & 9.9 \\
\hline 23 & Cheongja \#3 & Cooked w/ rice and others & 2004 & $\mathrm{P}$ & B & 32.1 \\
\hline 24 & Ilpumgeomjeong \#2 & Cooked w/ rice and others & 2005 & $\mathrm{P}$ & B & 25.0 \\
\hline 25 & Socheong & Cooked w/ rice and others & 2006 & $\mathrm{~W}$ & $\mathrm{~B}$ & 15.7 \\
\hline 26 & Socheong2 & Cooked w/ rice and others & 2009 & $\mathrm{~W}$ & B & 12.2 \\
\hline 27 & Socheongja & Cooked w/ rice and others & 2014 & $\mathrm{~W}$ & B & 12.0 \\
\hline 28 & Cheongja4 & Cooked w/ rice and others & 2015 & $\mathrm{P}$ & B & 30.1 \\
\hline
\end{tabular}

${ }^{\mathrm{a}}$ Flower color: $\mathrm{P}$ purple, $\mathrm{W}$ white

${ }^{\mathrm{b}}$ Seedcoat color: Y yellow, B black, PG pale green

\section{Results and discussion}

\section{Quantitative variation of isoflavone and its components based on planting time}

For the 28 domestically grown Korean soybean cultivars, the amount of total isoflavone and its component groups were analyzed for the three planting times over 2 years from 2017 to 2018. The results of the analyses of variance of the isoflavone and component content showed significant effects of genotypes, planting times, years and their interactions (Table 2).

The average isoflavone content increased overall as the seed planting time was delayed from late May to early July (Fig. 1). The average total isoflavone content over the 2 years was $2934 \mu \mathrm{g} / \mathrm{g}$ for the third planting in early July, which was higher than that for the first planting in late May and the second planting in mid-June $(2564 \mu \mathrm{g} / \mathrm{g}$ and $2790 \mu \mathrm{g} / \mathrm{g}$, respectively). Similar patterns of increases in isoflavone content were observed in the order of late May $<$ midJune $<$ early July for both years. The average isoflavone content of the harvested samples in $2017(3224 \mu \mathrm{g} / \mathrm{g})$ was higher than that of the samples in $2018(2303 \mu \mathrm{g} / \mathrm{g})$.

The quantitative variations of the isoflavone components based on the seed planting times are shown in Figs. 1 and 2. Similar to the total isoflavone content, the malonyl-based glucoside component, which accounted for the highest proportion of soybean isoflavone composition, increased significantly as the planting time was delayed. Despite the low composition ratio of isoflavones, the non-glycosylated aglycon group showed similar tendencies in content variation with that of the malonyl-based isoflavone group at the different planting times. In contrast, there was no specific trend in content variation for the glucoside-based isoflavone 
Table 2 Analyses of variance for total isoflavone and its component group contents of the 28 soybean cultivars grown at three different planting times over 2 years (2017 and 2018)

\begin{tabular}{|c|c|c|c|c|c|}
\hline SV & T_Aglycon & T_Glucoside & T_M_Glucoside & T_Ac_Glucoside & Total \\
\hline Genotype (G) & $182.6 * * * *$ & $146.4 * * * *$ & $664 * * * *$ & $316.4 * * * *$ & $665.3 * * * *$ \\
\hline Planting time $(\mathrm{P})$ & $166.5 * * * *$ & $25.3 * * * *$ & $514.4 * * * *$ & $319.3 * * * *$ & $310.4 * * * *$ \\
\hline Year (Y) & $57.5 * * * *$ & $0.2^{\mathrm{ns}}$ & $9400.6^{* * * *}$ & $5663.9 * * * *$ & $5645.0 * * * *$ \\
\hline $\mathrm{G} \times \mathrm{P}$ & $10.2 * * * *$ & $21.6 * * * *$ & $29.4 * * * *$ & $40.5 * * * *$ & $28.0 * * * *$ \\
\hline $\mathrm{G} \times \mathrm{Y}$ & $14.1 * * * *$ & $13.8 * * * *$ & $65.4 * * * *$ & $67.3 * * * *$ & $51.0 * * * *$ \\
\hline $\mathrm{G} \times \mathrm{P} \times \mathrm{Y}$ & $10.2 * * * *$ & $12.9 * * * *$ & $21.1 * * * *$ & $36.2 * * * *$ & $21.6^{* * * * *}$ \\
\hline $\mathrm{P} \times \mathrm{Y}$ & $133.5 * * * *$ & $83.9 * * * *$ & $9.1 * * * *$ & $666.4 * * * *$ & $25.6 * * * *$ \\
\hline C.V & 13.4 & 11.1 & 4.9 & 13.4 & 5.0 \\
\hline $\operatorname{LSD}(0.05)$ & 32.8 & 52.1 & 187.3 & 3.1 & 220.3 \\
\hline Mean (ug/g) & 152.4 & 293.3 & 2362.4 & 14.5 & 2762.7 \\
\hline
\end{tabular}

T_Aglycon: Daidzein + Glycitein + Genistein, T_Glucoside: Daidzin + Glycitin + Genistin

T_M_Glucoside: 6"-O-malonyldaidzin +6 "- $O$-malonylgenistin $+6 "$ - $O$-malonylglycitin

T_Ac_Glucoside: $6 "$ - $O$-acetyldaidzin $+6^{\prime \prime}$ - $O$-acetylgenistin $+6 "$ - $O$-acetylglycitin

Total: T_Aglycon + T_Glucoside + T_M_Glucoside + T_Ac_Glucoside

$* * * * p<0.0001, n s$ not significant group based on the planting time. Because the composition of the aglycon and glucoside groups made up a low proportion of the total isoflavone content, they had little effect on the variation in total isoflavone content.

As shown in Fig. 2, the quantitative variation of the isoflavone components that had relatively low content ratios, such as glycitein, glycitin, and malonylglycitin, was not large and was stable regardless of the planting time. Conversely, components such as genistein and daidzein in the aglycon group and malonylgenistin and malonyldaidzin in the malonyl group consistently increased as the planting time was delayed to early July; however, genistin and daidzin in the glucoside group did not increase after planting in midJune. The content of the acetyl glucoside group was too low $(15-22 \mu \mathrm{g} / \mathrm{g})$ to determine the content variation associated with the change in planting times. The annual variation in isoflavone content was significant except for the glucoside group and the interaction between cultivation year and planting time was significant for all component groups. Therefore, the accumulation of each isoflavone component varied differently to changes in the planting time owing to the variance in climatic and ecological environments over 2 years.

\section{Variation in isoflavone content of soybean cultivar groups at different planting times}

In the present study, the 28 soybean cultivars were grouped by end-use and their content variations of total isoflavone and component groups based on planting times are shown in Fig. 3. The average levels of isoflavone content were higher in the order of soybean cultivar groups for soy-sprout $>$ soypaste and tofu > cooking with rice without regard to planting times. This finding for the isoflavone levels of soybean groups by end-use was consistent with those of previous studies (Kim et al. 2019, 2018; Park et al. 2012). The isoflavone content was higher at planting in early July than that in late May and/or mid-June for the cultivars for soy-sprout and soy-paste and tofu, although not for the black soybean cultivars. The average isoflavone content of 11 cultivars for soy-sprout was $2992 \mu \mathrm{g} / \mathrm{g}$ for the late May planting, $3335 \mu \mathrm{g} / \mathrm{g}$ in mid-June, and $3372 \mu \mathrm{g} / \mathrm{g}$ in early July; however, a significant difference was not observed between the mid-June and early July plantings. The average isoflavone content of the 11 cultivars for soy-paste and tofu also varied depending on planting time, i.e., $2270 \mu \mathrm{g} / \mathrm{g}$ for the late May planting, $2514 \mu \mathrm{g} / \mathrm{g}$ in mid-June, and $2826 \mu \mathrm{g} / \mathrm{g}$ in early July, and their variation in isoflavone content was significant Yun et al. (2006) reported that isoflavone content increased as the planting time was delayed regardless of the ecological type of soybean studied as seen in the early-matured or mid- to late-matured cultivars. In a study by Sakai et al. (2005), the isoflavone content of the soybean was not related to seed shape (i.e., seed color and size) but was significantly correlated with the planting period. Therefore, the isoflavone content of soybean seeds is affected by environmental factors during different planting periods regardless of the maturity of the cultivars.

Correlations of the average isoflavone contents of the 28 soybean cultivars grown at the three different planting times over 2 years were in the range of $0.81-0.93$ with statistical significance $(p<0.0001)$ (Fig. 4). Correlations of the 28 soybean cultivars among the planting time treatments were $0.8-0.93$ in 2017 and $0.62-0.78$ in 2018. Therefore, the relative ranks of the 28 soybean cultivars changed with variation in their isoflavone content over the planting periods. Despite the significant interactions of cultivars with planting time and years, some soybean cultivars more stably maintained high or low levels of isoflavone content 
Fig. 1 Variation in the contents of total isoflavone and the four component groups of aglycon, glucoside, malonylglucoside, and acetylglucoside at three different planting times for the 28 soybean cultivars: $\mathbf{A}$ over 2 years of 2017-2018, B in 2017, and $\mathbf{C}$ in 2018

\section{(A)}

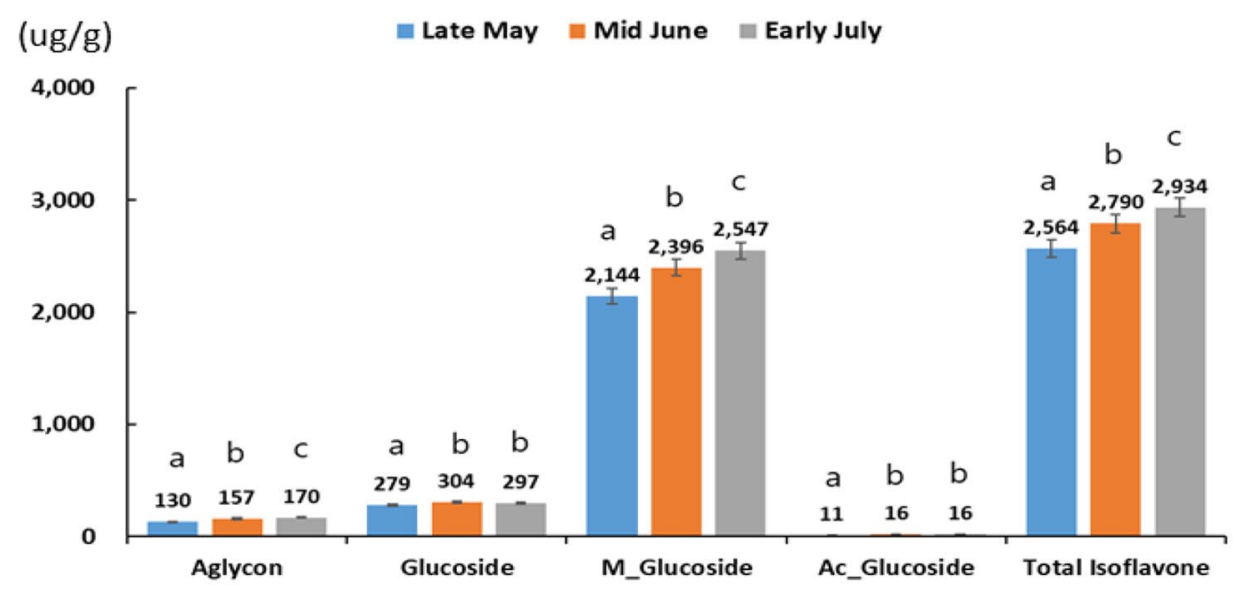

(B)

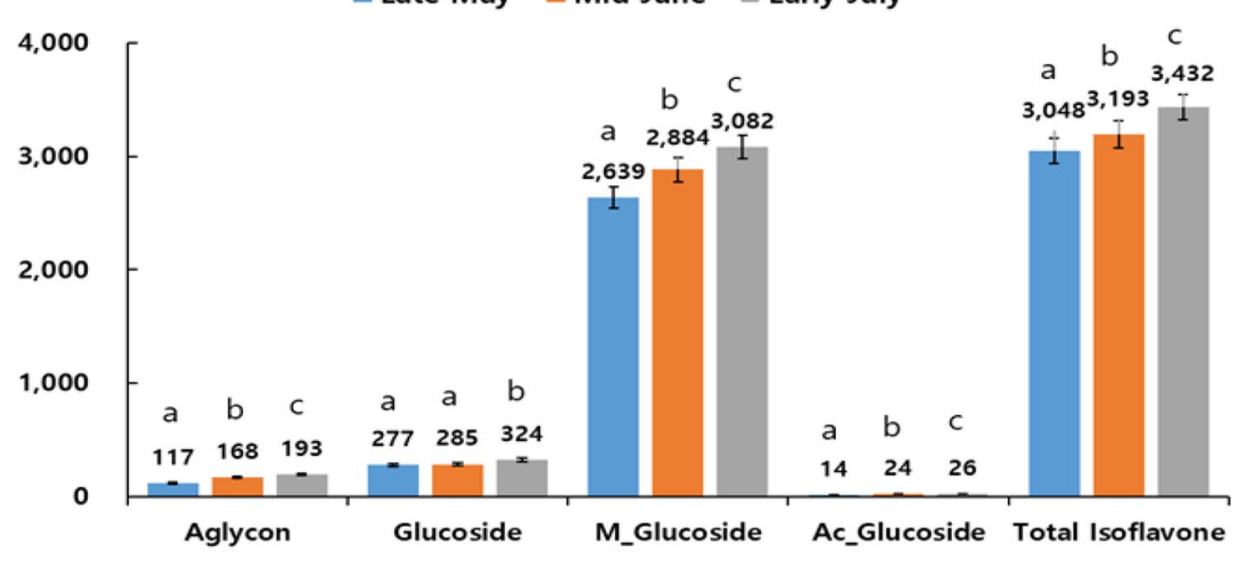

(C)

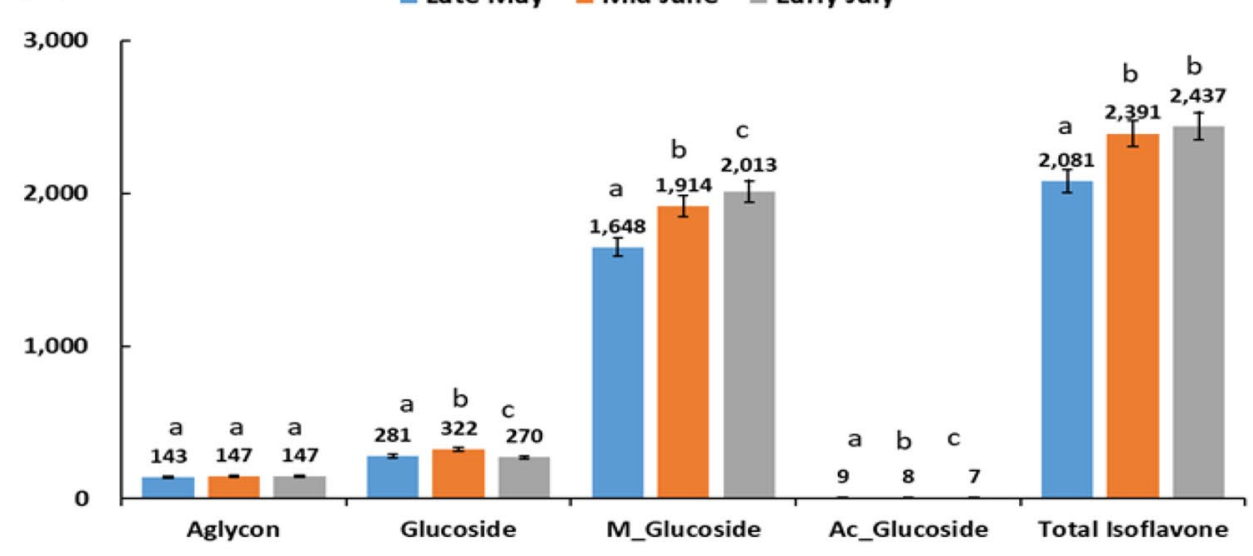

than others. Based on the average isoflavone content over 2 years, the soybean cultivars with high values were "Jinpung" (3715 ug/g), "Uram" (3685 ug/g), and "Daepung2ho" (3659 ug/g) for soy-paste and tofu, and "Sorok" (4474 ug/g),
"Haewon" (4074 ug/g), "Wonkwang" (3626 ug/g), and "Sinhwa" (3361 ug/g) for soy-sprout. In contrast, the soybean cultivars with low isoflavone content were "Taekwangkong" $(1326 \mathrm{ug} / \mathrm{g})$ and "Saedanbaek" (1398 ug/g) for soy-paste and 
Fig. 2 Changes in the contents of the 12 isoflavone components in the aglycon, glucoside, malonylglucoside, and acetylglucoside groups at three planting times for the 28 soybean cultivars over 2 years (2017-2018)
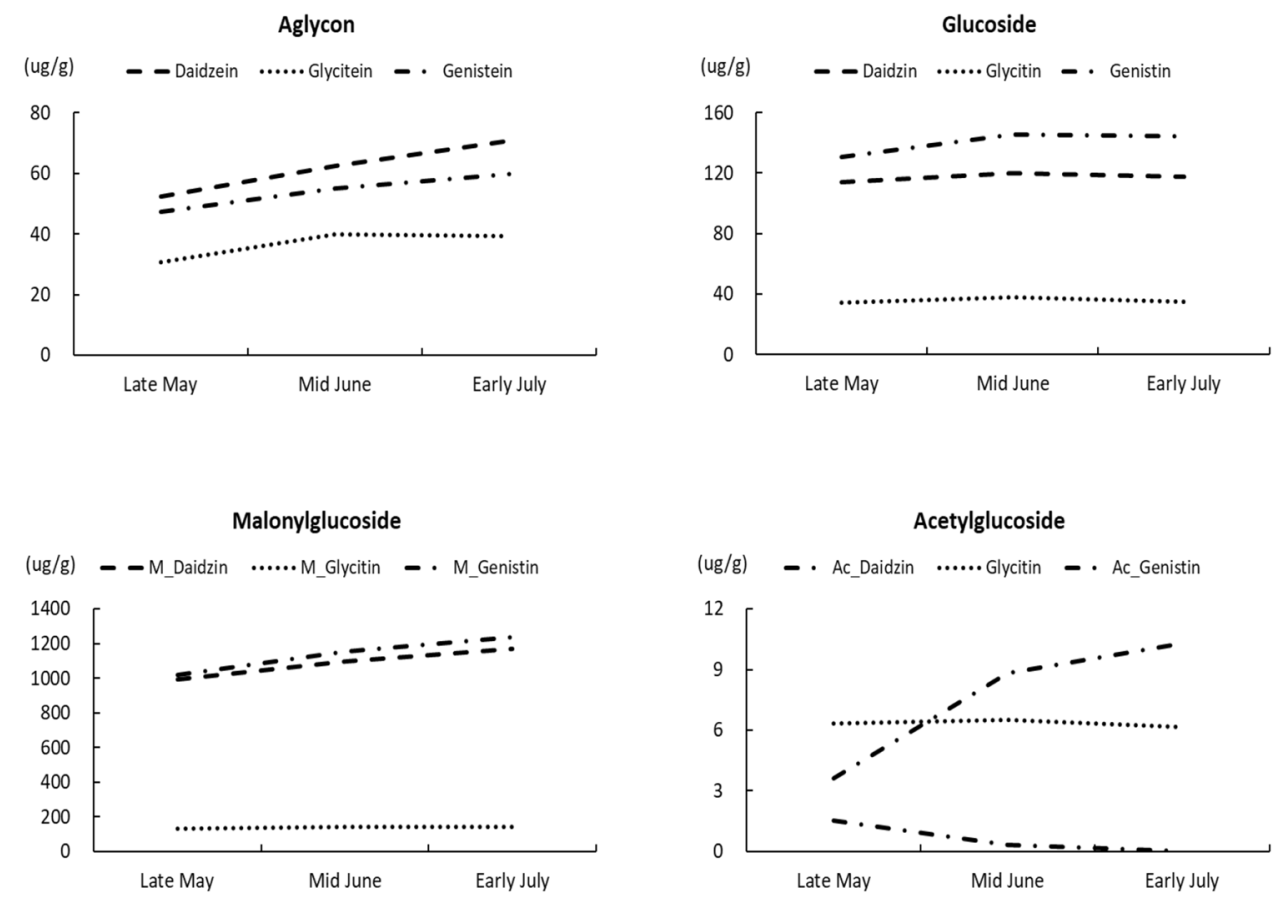

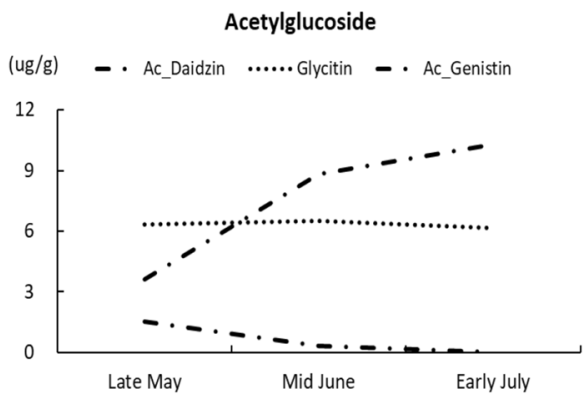

tofu and "Sohwang" (1684 ug/g) for soy-sprout. The average isoflavone contents of the six black soybean cultivars for cooking with rice were in the range of $1765 \mathrm{ug} / \mathrm{g}$ ("Cheongja 4 ")-2,906 ug/g ("Socheong"). The quantitatively stable variations of soybean cultivars identified with high or low isoflavone contents over different planting times in the present study were consistent with the results of a previous study (Kim et al. 2019).

Table 3 shows the distribution of the 28 soybean cultivars by isoflavone content range averaged over 2017-2018 based on the planting period from late May to early July. Responses such as a trend of increase or decrease concerning the variation of the isoflavone content were different for each cultivar. Except for some cultivars such as "Sorok", "Sohwang", "Socheongja", and "Socheong", most cultivars including "Daepung2ho", "Jinpung", and "Shinhwa" showed an increased isoflavone content at planting in mid-June and early July rather than in late May. As shown in Fig. 5, cultivars including "Daepung2ho", "Sinhwa", and "Cheongja4" showed a significant increase in isoflavone content that was $7-16 \%$ higher when planted in mid-June than that in late May and was 5-8\% higher when planted in mid-June than that in early July. Conversely, for "Uram", there was no change in the content until planting in mid-June, but it increased when planting in early July. The isoflavone content of "Haewon" increased after planting in late May; however, there was little change in the content when planting occurred in mid-June and early July. "Socheongja" was a non-consistent cultivar whose isoflavone content decreased even after planting in early July. These results suggest that diverse interactions of individual soybean cultivars with the ecological environment during the ripening period based on the planting time might influence the synthesis and accumulation of isoflavone. Yi and Yoon (2012) found that the variations in the time and speed of isoflavone accumulation were different based on the soybean cultivars or planting time when monitored until maturation after flowering of black soybean cultivars.

\section{Effect of the growth environment and climatic change after different planting times on isoflavone content}

As the planting time of the cultivars was late in the present study, the flowering and maturity of the soybean cultivars were delayed and the number of days of growth from planting or flowering to maturity decreased. This was because the time required for vegetative growth was shortened and the conversion to reproductive growth was faster as the soybean plants responded to shorter day length conditions due to late planting. The ecological responses of soybean cultivars during the growth period varied based on the weather environment differences in the different cultivation years.

In 2018, the planting time was 2-6 days earlier than in 2017; however, maturity was delayed by approximately 1-6 days. Therefore, the average number of days from flowering to maturity was approximately 4-8 days higher in 2018 than that in 2017. In the present study, the change in the number of growth days by planting time had little effect on isoflavone content. There was no significant correlation between the number of days of growth from flowering to maturity and isoflavone content in the 28 soybean cultivars 
Fig. 3 Variation in the contents of total isoflavone and the 4 component groups of aglycon, glucoside, malonylglucoside, and acetylglucoside at three different planting times for the 28 soybean cultivars grouped by their end-uses over 2 years (2017-2018): A 11 cultivars for soy-paste and tofu, B 11 cultivars for soy-sprout, and $\mathbf{C}$ six cultivars for cooking with rice
(A)

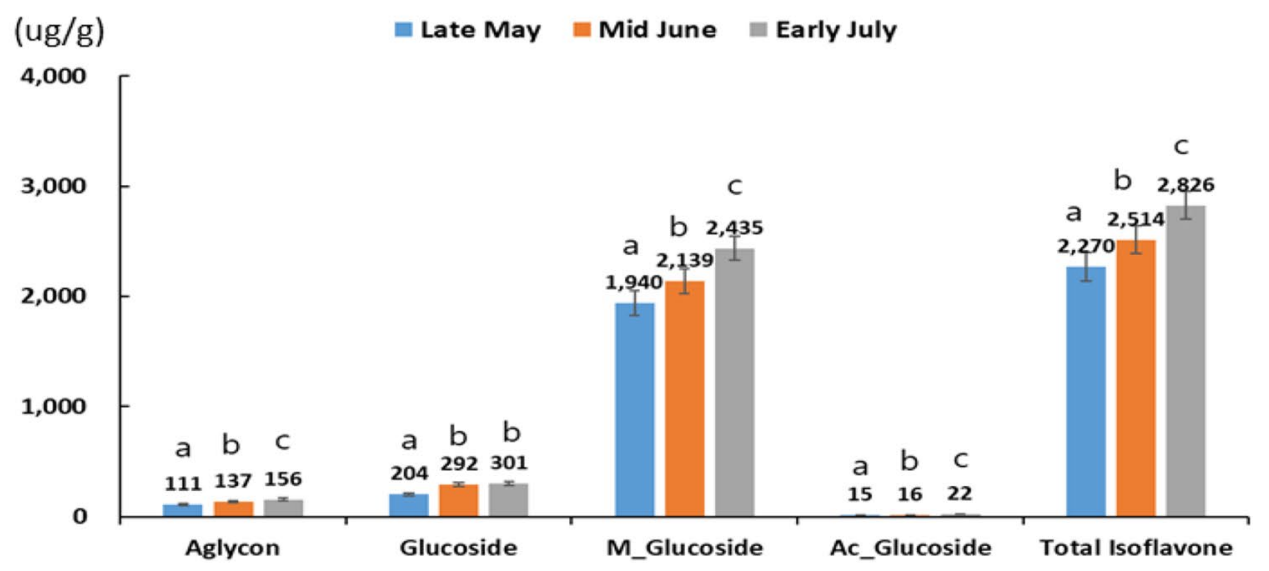

(B)

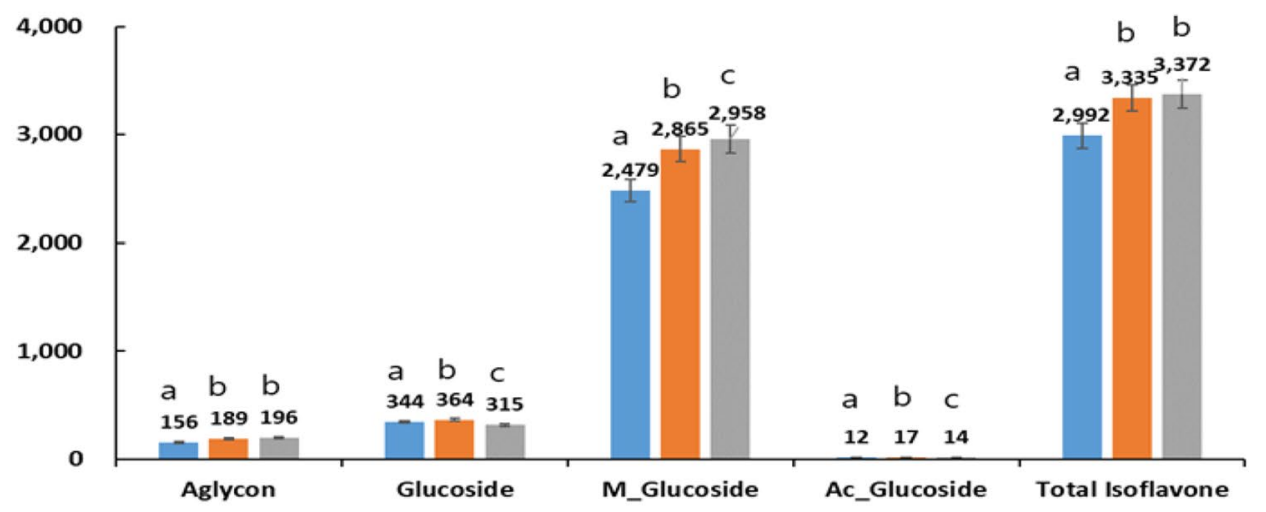

(C)

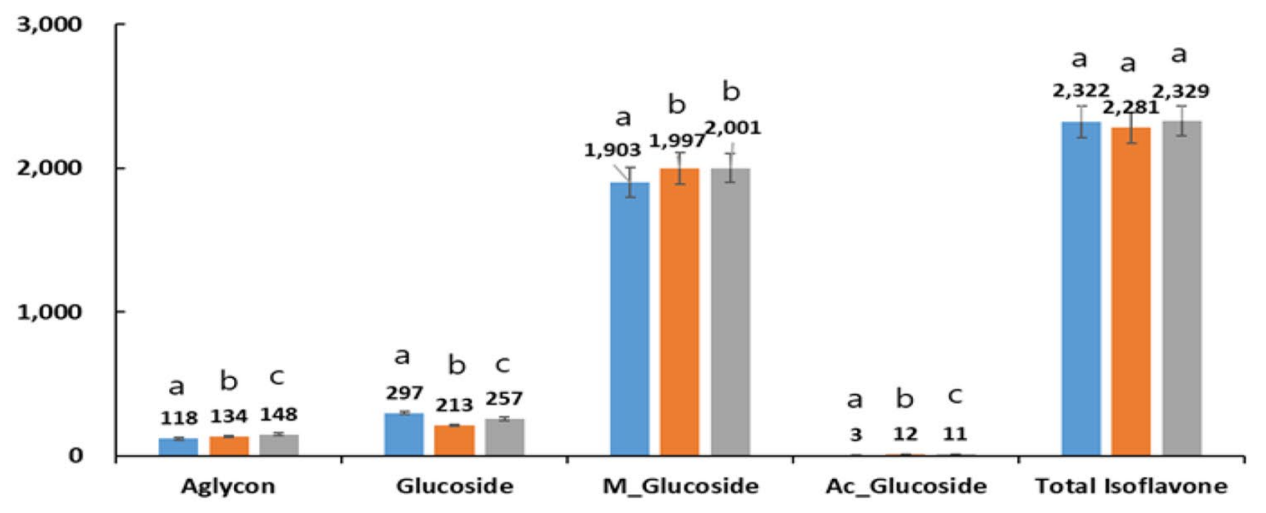

in 2017 and 2018 (data not shown). Early-matured soybean cultivars with fewer numbers of growth days have a lower content of isoflavones than mid- or late-matured cultivars (Kim et al. 2019; Sakai et al. 2005; Yun et al. 2006). However, the isoflavone content of the soybean cultivars with similar ranges of early- or late-maturity was not significantly affected by the number of days of growth from planting or flowering to maturity (Kim et al. 2019).

If planted later than the proper planting time, the seed weight of some soybean cultivars might decrease because of the shortening of the maturity period not being adequate for seed ripening and enlargement. The correlation between 
(A)

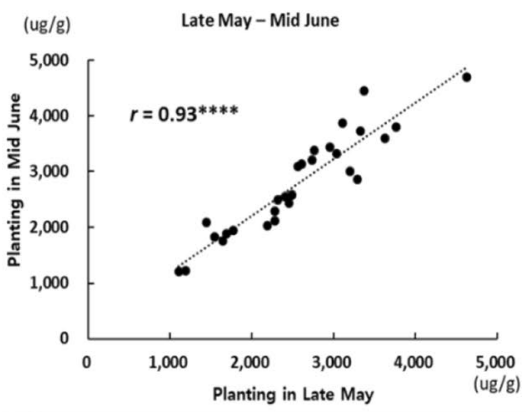

(B)

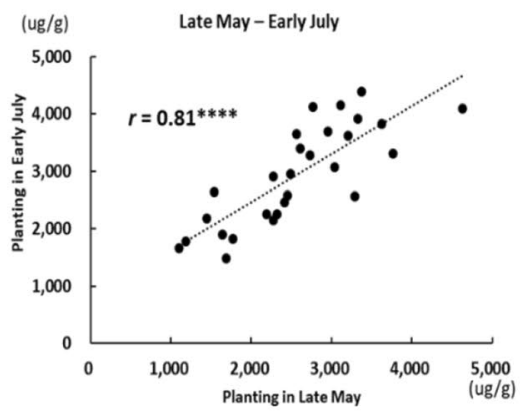

(C)

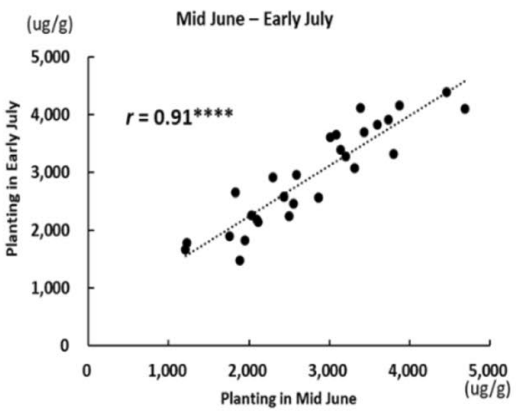

Fig. 4 Correlations of total isoflavone contents of the 28 soybean cultivars at three different planting times over 2 years (2017-2018): A plantings in late May and mid-June, $\mathbf{B}$ plantings in late May and early July, and $\mathbf{C}$ plantings in mid-June and early July

Table 3 Distribution of the 28 soybean cultivars by average content of total isoflavone at three different planting times from 2017 to 2018

\begin{tabular}{|c|c|c|c|c|}
\hline \multirow{2}{*}{$\begin{array}{l}\text { Isoflavone } \\
\text { content } \\
\text { (ug/g) }\end{array}$} & \multirow[t]{2}{*}{ End-use } & \multicolumn{3}{|l|}{ Planting time } \\
\hline & & Late May & Mid-June & Early July \\
\hline \multirow[t]{3}{*}{$4500-5000$} & Soy-paste and Tofu & - & - & - \\
\hline & Soy-sprout & Sorog & Sorog & - \\
\hline & Cooking w/ rice & - & - & - \\
\hline \multirow[t]{3}{*}{$4000-4500$} & Soy-paste and Tofu & - & - & Jinpung \\
\hline & Soy-sprout & - & Haewon & Haewon, Pungwon, Sorog \\
\hline & Cooking w/ rice & - & - & - \\
\hline \multirow[t]{3}{*}{$3500-4000$} & Soy-paste and Tofu & Uram & Jinpung, Daepung2ho, Uram & Daepung2ho, Uram \\
\hline & Soy-sprout & Wongwang & Wongwang & Sinhwa, Soyeon, Haepum \\
\hline & Cooking w/ rice & - & - & - \\
\hline \multirow[t]{3}{*}{$3000-3500$} & Soy-paste and Tofu & Daepung2ho, Jinpung & Seonpung & Seonpung \\
\hline & Soy-sprout & Haewon, Haepum, Aram & $\begin{array}{l}\text { Sinhwa, Pungwon, Aram, Bosug, } \\
\text { Soyeon, Haepum }\end{array}$ & Bosug, Wongwang, Aram \\
\hline & Cooking w/ rice & Socheong & - & - \\
\hline \multirow[t]{3}{*}{$2500-3000$} & Soy-paste and Tofu & Seonpung & Miso & Daechan, Taeseon \\
\hline & Soy-sprout & Sinhwa, Pungwon, Bosug, Soyeon & - & - \\
\hline & Cooking w/ rice & - & Socheong, Ilpumgeomjeong \#2 & $\begin{array}{l}\text { Ilpumgeomjeong \#2, } \\
\text { Socheong2, Socheong }\end{array}$ \\
\hline \multirow[t]{3}{*}{$2000-2500$} & Soy-paste and Tofu & Miso, Daechan, Daewonkong & Daechan, Neulchan, Daewonkong & Miso, Daewonkong, Neulchan \\
\hline & Soy-sprout & Pungsannamulkong & Pungsannamulkong & Pungsannamulkong \\
\hline & Cooking w/ rice & $\begin{array}{l}\text { Ilpumgeomjeong \#2, Socheong2, } \\
\text { Cheongja \#3 }\end{array}$ & Socheong2, Cheongja \#3 & Cheongja \#3 \\
\hline \multirow[t]{3}{*}{$1500-2000$} & Soy-paste and Tofu & Taeseon & Taeseon & Saedanbaek, Taekwangkong \\
\hline & Soy-sprout & Sohwang & Sohwang & - \\
\hline & Cooking w/ rice & Socheongja, Cheongja4 & Socheongja, Cheongja4 & Cheongja4, Socheongja \\
\hline \multirow[t]{3}{*}{$<1500$} & Soy-paste and Tofu & Neulchan, Saedanbaek, Taekwangkong & Saedanbaek, Taekwangkong & - \\
\hline & Soy-sprout & - & - & Sohwang \\
\hline & Cooking w/ rice & - & - & - \\
\hline
\end{tabular}

the number of growth days from flowering to maturity and the 100-seed weight of the 28 cultivars for all planting times in the present study was $0.53(p<0.01)$ in 2018 and $0.23(p>0.05)$ in 2017. As suggested in previous studies (Kim et al. 2019; Yun et al. 2006), the trend was that the larger the seed size, the lower the isoflavone content of the soybean cultivars. In our study, the correlation was not statistically significant except for those at the plantings of late May $(r=-0.41, p<0.05)$ and mid-June $(r=-0.44$, $p<0.05$ ) in 2018, respectively (Fig. 6). Regardless of the 
$<$ For soy-paste $\&$ tofu >

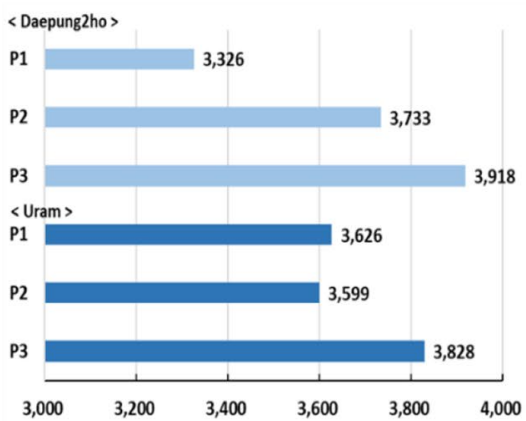

< For soy-sprout >

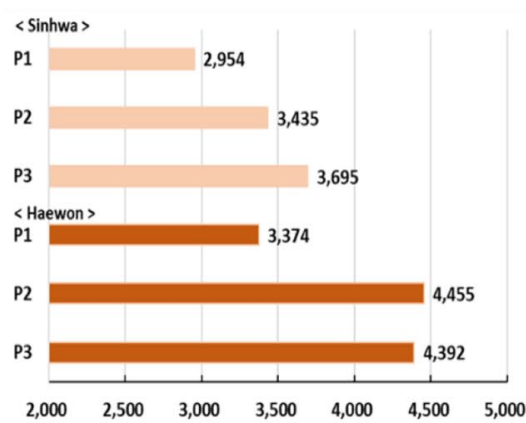

$<$ For cooking with rice >

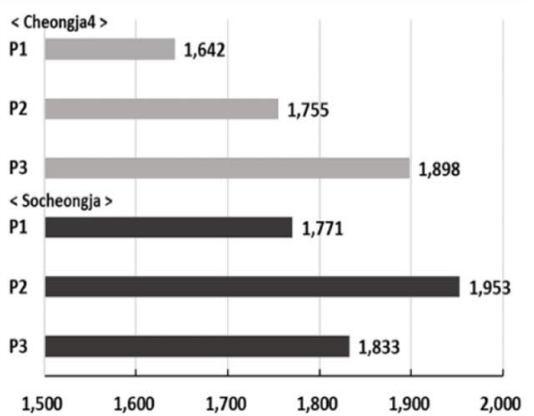

Fig. 5 Variation in the total isoflavone contents of some soybean cultivars grouped by their end-uses for three different planting times of late May (P1), mid-June (P2), and early July (P3) over 2 years (2017-2018)

planting period, the soybean cultivars for soy-sprout had a smaller seed size and higher isoflavone content than those for soy-paste and tofu and for cooking with rice. Black soybean cultivars with large seed sizes have relatively lower isoflavone content than that of other cultivars. The traits of seed size and isoflavone content of the soybean cultivars classified by their end-uses might have some influence on their correlation.

As the flowering and maturity of the soybean cultivars were delayed owing to late planting, the daily average temperature and the highest and lowest temperatures during the flowering and maturity periods of each cultivar were
Fig. 6 Correlation of 100-seed weight with total isoflavone content for the 28 soybean cultivars grown at three different planting times in 2017 and 2018

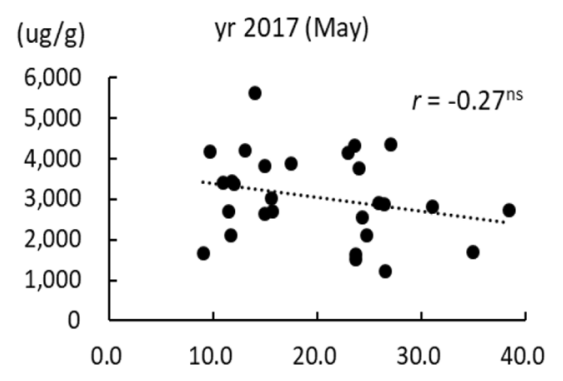

yr 2017 (June)

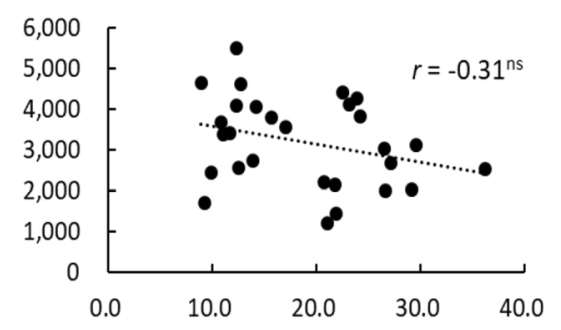

yr 2017 (July)

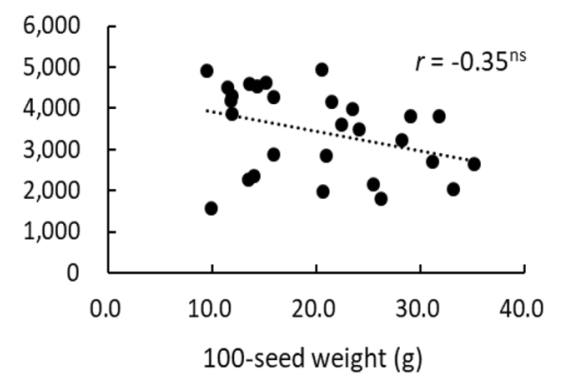

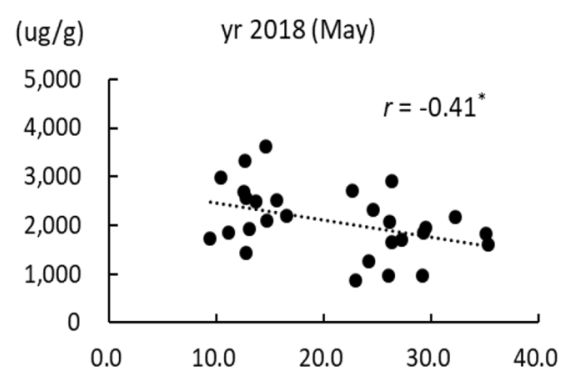

yr 2018 (June)

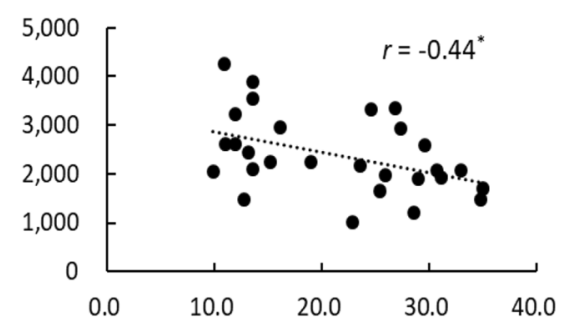

yr 2018 (July)

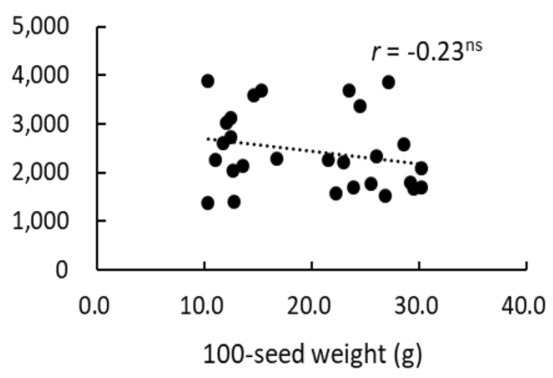


lowered, as shown in Table 4. In particular, a decrease in the average temperature of approximately $2{ }^{\circ} \mathrm{C}$ at the planting in July compared to that in June was greater than the decrease of approximately $1{ }^{\circ} \mathrm{C}$ at the planting in June compared to that in May. There was an inverse correlation between the average temperature in the flowering-maturity period and isoflavone content regardless of the planting time; however, no statistical significance was observed (Fig. 7). The range of average temperature during the flowering-maturity period of the 28 soybean cultivars was greater owing to an abnormal heatwave and large temperature variation in July-September in 2018 compared to 2017. Yearly differences in climatic conditions, especially during the ripening stage of soybeans, might affect the accumulation of isoflavone. According to previous studies, the synthesis and accumulation of soybean isoflavone components are sensitive to temperature changes in cultivation environments (Britz et al. 2011; Chennupati et al. 2012; Hong et al. 2018; Tsukamoto et al. 1995). In a study by Britz et al. (2011), the variation in isoflavone content of early-matured soybean cultivars was sensitive to changes in temperature and precipitation and the isoflavone content was decreased by $50 \%$ under warm conditions.

Table 4 Average values of the 28 soybean cultivars by flowering and maturing dates, number of growth days, 100-seed weight, and air temperatures (mean, highest, and lowest) in 2017 and 2018 at 3 planting times

\begin{tabular}{|c|c|c|c|c|c|c|c|c|c|}
\hline $\begin{array}{l}\text { Planting } \\
\text { Time }^{\mathrm{a}}\end{array}$ & Year & $\begin{array}{l}\text { Flowering } \\
\text { date }\end{array}$ & Maturing date & $\begin{array}{l}\text { No. of days } \\
\text { (planting- } \\
\text { maturity) }\end{array}$ & $\begin{array}{l}\text { No. of days } \\
\text { (flowering- } \\
\text { maturity) }\end{array}$ & $\begin{array}{l}\text { 100-Seed } \\
\text { weight } \\
\text { (g) }\end{array}$ & $\begin{array}{l}\text { Mean } \\
\text { temp } \\
\left({ }^{\circ} \mathrm{C}\right)\end{array}$ & $\begin{array}{l}\text { High temp }{ }^{b} \\
\left({ }^{\circ} \mathrm{C}\right)\end{array}$ & Low temp ${ }^{\mathrm{b}}\left({ }^{\circ} \mathrm{C}\right)$ \\
\hline \multirow[t]{2}{*}{ Late May } & 2017 & 7.22 & 10.10 & 133.9 & 80.8 & 20.0 & 23.7 & 28.8 & 19.4 \\
\hline & 2018 & 7.23 & 10.16 & 146.5 & 85.1 & 21.0 & 23.6 & 28.4 & 19.5 \\
\hline \multirow[t]{2}{*}{ Mid June } & 2017 & 8.4 & 10.14 & 121.8 & 71.4 & 18.8 & 22.8 & 27.8 & 18.5 \\
\hline & 2018 & 7.30 & 10.16 & 126.9 & 78.2 & 21.4 & 22.7 & 27.6 & 18.6 \\
\hline \multirow[t]{2}{*}{ Early July } & 2017 & 8.19 & 10.22 & 103.8 & 64.4 & 20.1 & 21.1 & 26.2 & 16.6 \\
\hline & 2018 & 8.11 & 10.23 & 112.0 & 73.0 & 19.9 & 20.8 & 25.7 & 16.6 \\
\hline
\end{tabular}

${ }^{a}$ Planting times (month.date): Late May [(2017) 5.29, (2018) 5.23], Mid June (6.14, 6.12), Early July (7.10, 7.4)

${ }^{\mathrm{b}}$ Air temperature (mean, highest, lowest) values at different planting times were average calculated in the period from flowering to maturity for 28 soybean cultivars in each year

Fig. 7 Correlation of average temperature during the flowering to maturity periods with total isoflavone content for the 28 soybean cultivars grown at three different planting times in 2017 and 2018
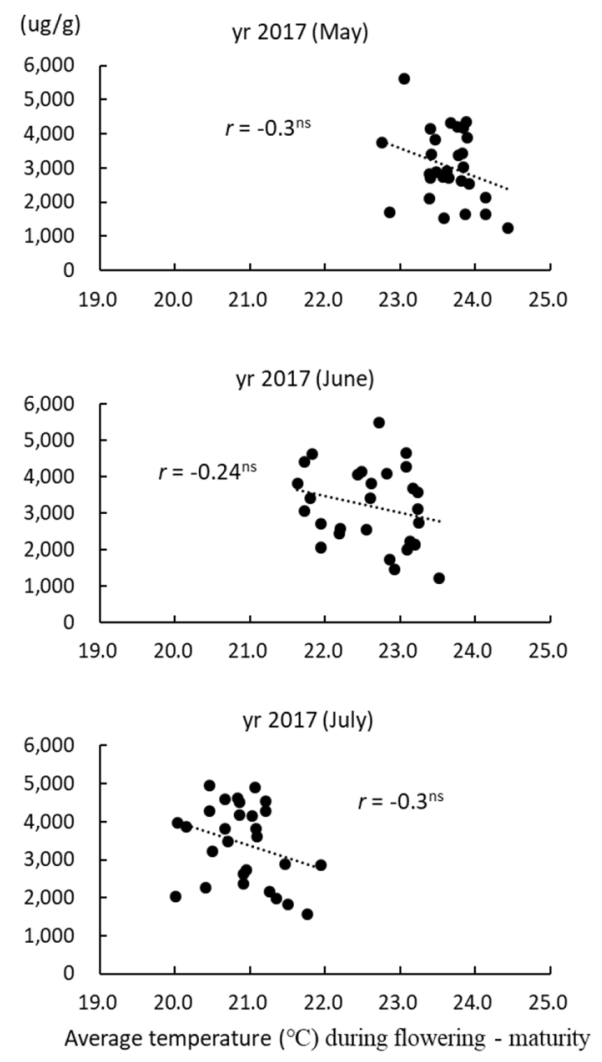
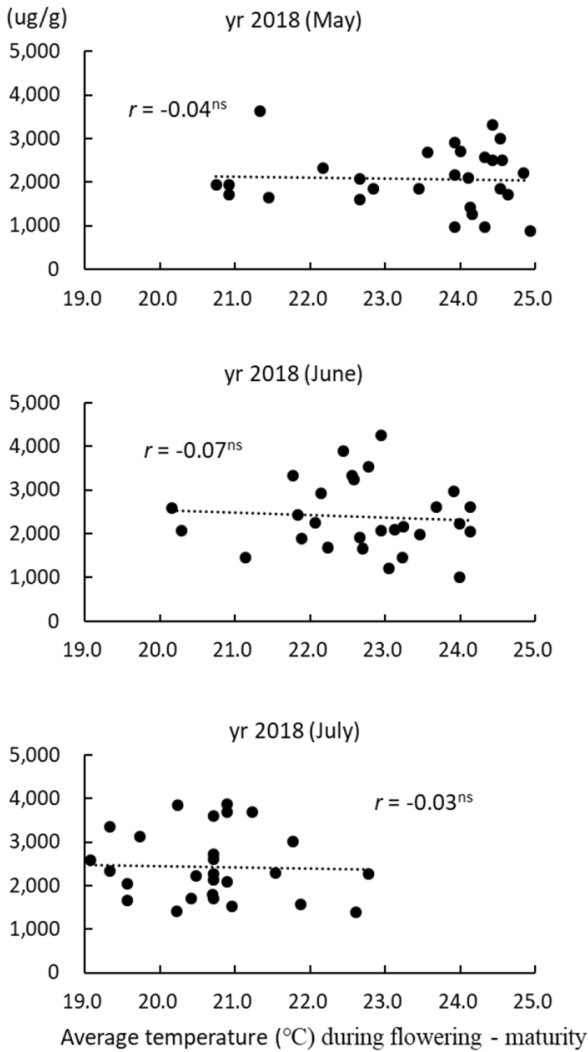
According to Hong et al. (2018), the higher the cultivation area altitude, the higher the isoflavone content of soybeans produced in the highlands where isoflavone content was affected by the low temperature at maturity. According to Chennupati et al. (2012), the inhibition of the accumulation of isoflavones in seeds under high temperature conditions was particularly remarkable during the late growth period of soybeans from seed development to maturity. In addition, the expression level of the related genes of isoflavone synthesis was different for each growth period.

In the present study, we found that the changes in the ecological environmental factors such as low temperature during the ripening period in association with changes in the planting period influenced the isoflavone content of the soybean. Because the isoflavone content varied depending on the soybean cultivars and planting periods, it is necessary to examine the possibility of improving the soybean isoflavone content using the planting time while considering the environmental factors of the cultivation area. Despite the interaction between the soybean cultivars and planting period, it would be advantageous to select cultivars with consistently high levels of isoflavone content regardless of the planting time. As demand for higher soy isoflavones grows, the production of soybeans with enhanced functional ingredients is important as an industrial material, as well as for human diets. The development of agricultural production technology for optimal varieties and the improvement of useful ingredients will result in an increase in soybean production and consumption via the creation of new values and demand for food crops.

Acknowledgements This research was supported by the Rural Development Administration Agenda Project (No. PJ01251203), Republic of Korea.

\section{Compliance with ethical standards}

Conflict of interest The authors declare that they have no conflict of interest.

Open Access This article is licensed under a Creative Commons Attribution 4.0 International License, which permits use, sharing, adaptation, distribution and reproduction in any medium or format, as long as you give appropriate credit to the original author(s) and the source, provide a link to the Creative Commons licence, and indicate if changes were made. The images or other third party material in this article are included in the article's Creative Commons licence, unless indicated otherwise in a credit line to the material. If material is not included in the article's Creative Commons licence and your intended use is not permitted by statutory regulation or exceeds the permitted use, you will need to obtain permission directly from the copyright holder. To view a copy of this licence, visit http://creativecommons.org/licenses/by/4.0/.

\section{References}

Aliferis KA, Faubert D, Jabaji S (2014) A metabolic profiling strategy for the dissection of plant defense against fungal pathogens. PLoS ONE 9(11):e111930. https://doi.org/10.1371/journal.pone.01119 30

Britz SJ, Schomburg CJ, Kenworthy WJ (2011) Isoflavone in seeds of field-grown soybean: variation among genetic lines and environmental effects. J Am Oil Chem Soc 88:827-832

Carrera C, Martinez MJ, Dardanelli J, Balzarini M (2011) Environmental variation and correlation of seed components in nontransgenic soybeans: protein, oil, unsaturated fatty acids, tocopherols, and isoflavones. Crop Sci 51:800-809

Chennupati P, Seguin P, Chamoun R, Jabaji S (2012) Effects of hightemperature stress on soybean isoflavone concentration and expression of key genes involved in isoflavone synthesis. J Agric Food Chem 60:12421-12427

Gutierrez-Gonzalez JJ, Guttikonda SK, Tran LS, Aldrich DL, Zhong R, Yu O, Nguyen HT, Sleper DA (2010) Differential expression of isoflavone biosynthetic genes in soybean during water deficits. Plant Cell Physiol 51:936-948

Hasanah Y, Nisa TC, Armidin H, Hanum H (2015) Isoflavone content of soybean (Glycine max (L.) Merr.) cultivars with different nitrogen sources and growing season under dry land conditions. J Agric Env Int Devel. 109:5-17

Hoeck JA, Fehr WR, Murphy PA, Welke GA (2000) Influence of genotype and environment on isoflavone contents of soybean. Crop Sci 40:48-51

Hong SY, Kim SJ, Sohn HB, Kim YH, Cho KS (2018) Comparison of isoflavone content in 43 soybean varieties adapted to highland cultivation areas. Korean J Breed Sci 50:442-452

Kim JS, Kwon CS (2001) Estimated dietary isoflavone intake of Korean population based on national nutrition survey. Nutr Res 21:947-953

Kim HM, Jang EK, Gwak BS, Hwang TY, Yun GS, Hwang SG, Jeong HS, Kim HS (2018) Variation of isoflavone contents and classification using multivariate analysis in Korean soybean varieties released from 1913 to 2013. Kor J Breed Sci 50:50-60

Kim HS, Kang BK, Seo JH, Ha TJ, Kim HT, Shin SO, Park CH, Kwak DY (2019) Quantitative variation of total seed isoflavone and its compositions in Korean soybean cultivars (Glycine max (L.) Merr.). Korean J Crop Sci 64:89-101

Lee SJ, Yan W, Ahn JK, Chung IM (2003) Effects of year, site, genotype and their interactions on various soybean isoflavones. Field Crops Res 81:181-192

Lee SK, Lee YS, Ji SH, Jo GS, Kang JH (2019) Effect on bone formation of fermented soybeans by combination treatment with highisoflavone aglycone ratios. Korean J Food Preserv 26:814-820

Messina M (2000) Soyfoods, soybean isoflavones, and bone health: a brief overview. J Renal Nutr 10:63-68

Murphy SE, Lee EA, Woodrow L, Seguin P, Kumar J, Rajcan I, Ablett GR (2009) Genotype $\times$ environment interaction and stability for isoflavone content in soybean. Crop Sci 49:1313-1321

Park KH, Piao XM, Jang EK, Yoo YE, Hwang TY, Kim SL, Jong JH, Shin HM, Kim HS (2012) Variation of isoflavone contents in Korean soybean cultivars released from 1913 to 2006. Kor J Breed Sci 44:149-159

Phillips DA, Kapulnik Y (1995) Plant isoflavonoids, pathogens and symbionts. Trends in Microbiol 3:58-64

Sakai T, Kikuchi A, Shimada H, Takada Y, Kono Y, Shimada S (2005) Evaluation of isoflavone contents and compositions of soybean seed and its relation with seeding time. Jpn J Crop Sci 74:156-164

Tsukamoto C, Shimada S, Ijta K, Kudou S, Kokubun M, Okubo K, Kitamura K (1995) Factors affecting isoflavone content in soybean seed: changes in isoflavons, saponins and composition of fatty 
acids at different temperatures during seed development. J Agri Food Chem 43:1184-1192

Yi ES, Yoon ST (2012) Changes of isoflavone contents during maturation under different planting dates in black soybean. Korean J Crop Sci 57:424-429
Yun HT, Kim WH, Lee YH, Suh SJ, Kim SJ (2006) Isoflavone contents of soybean according to different planting dates. Korean J Crop Sci 51:174-178 